\title{
The dynamics of entry mode choice in challenging business environments: an exploratory study of medium sized exporters' entry into Africa
}

\section{Henrik Gundelach* and Michael W. Hansen}

\author{
Department of Management, Society and Communication, \\ Centre for Business and Development Studies, \\ Copenhagen Business School, \\ Dalgas Have 15, DK-2000 Frederiksberg, Denmark \\ Email: hg.msc@cbs.dk \\ Email: mwh.msc@cbs.dk \\ *Corresponding author
}

\begin{abstract}
This article studies the entry modes adopted by medium-sized enterprises (MEs) seeking market access to challenging business environments in Africa. Based on a review of the extant literature on entry mode choice and organisational learning in internationalisation, we develop a dynamic model for analysing entry mode choice of exporting MEs. Via a longitudinal study of 14 Danish MEs' attempted entry into the Kenyan market, we found that gaining better knowledge of own resources in relation to the Kenyan business environment did not make the MEs adjust their entry mode. The only behavioural adjustments in lieu of better knowledge were that several MEs, rather than changing their preferred entry mode, decided to abandon entry altogether. We ascribe this lack of adaptation of entry mode strategy to organisational inertia. In conclusion, we argue that our findings have important implications for the theory of organisational learning in internationalisation.
\end{abstract}

Keywords: export; internationalisation; Uppsala model; Africa; entry modes; challenging business environments; resource-based view; RBV; institutional perspective; medium-sized enterprises; MEs; path dependency; experiential learning; inertia.

Reference to this paper should be made as follows: Gundelach, H. and Hansen, M.W. (2020) 'The dynamics of entry mode choice in challenging business environments: an exploratory study of medium sized exporters' entry into Africa', Int. J. Export Marketing, Vol. 3, No. 3, pp.174-203.

Biographical notes: Henrik Gundelach is a $\mathrm{PhD}$ Fellow at the Copenhagen Business School, Copenhagen. His research interests are placed in the intersection between business and development with a particular focus on market entry and the subsequent drivers of firm performance. He received his MBA from INSEAD, France, and he has been a Visiting Fellow at the University of Sydney. His research is mainly contextualised in East Africa, and he grounds his research in an extensive managerial career in the global food industry.

Michael W. Hansen is an Associate Professor at the Copenhagen Business School, Denmark. His research interest is related to firm strategy, organisation and management in emerging markets and developing countries. A key theme is market entry and subsequent survival strategies in emerging markets and 
developing countries. He earned his $\mathrm{PhD}$ from the Copenhagen Business School, and he has written extensively about MNCs' engagements in Asia and Africa.

This paper is a revised and expanded version of a paper entitled 'Early stage internationalisation in challenging business environments - an exploratory study of modes adopted by medium-sized enterprises seeking market entry in Kenya' presented at ANZIBA 2019, Perth, Australia, 11-13 February 2019.

\section{Introduction}

Increasingly, European exporters are looking to Africa as the next significant opportunity in developing markets (Tvedten et al., 2014). Greater political stability, high economic growth rates, and improving business environments have offered opportunities for foreign firms to obtain first-mover advantages. The opening of African markets has attracted large European multinational corporations (MNCs) as well as small entrepreneurial firms. European medium-sized enterprises (MEs) also see many opportunities in African markets, but they are weakly represented here (Dansk Industri, 2016). Even if there are significant market opportunities, and even if MEs typically have substantial export experience, they struggle to overcome the combination of the challenging business environments in Africa and internal resource constraints.

The challenges are partly due to considerable differences in the institutional environment between the exporter's home country and an African market, conceptualised by institutional distance (Kostova, 1999; Kostova and Zaheer, 1999) and institutional uncertainty (Getachew and Beamish, 2017; Khanna and Palepu, 2010). The substantial institutional differences combined with the exporting MEs' lack of experience with the African markets place them in a precarious position with a high liability of foreignness (Kostova and Zaheer, 1999; Zaheer, 1995). Nevertheless, some exporting MEs succeed in overcoming the challenges and enter the African markets.

The entry modes of exporters was the focus of much earlier international business (IB) literature (e.g., Brouthers and Nakos, 2004; Buckley and Casson, 1998; Davis et al., 2000; Johanson and Vahlne, 1990, 1977) but has since disappeared from the core interest of IB and become replaced with an interest in high commitment and multi-location entry modes (Canabal and White, 2008; Laufs and Schwens, 2014; Schellenberg et al., 2018). Hence, IB research has moved toward a focus on MNCs (Laufs and Schwens, 2014) or small entrepreneurial firms (Peng, 2001). This has made several authors note that there is a 'missing middle' in IB internationalisation research (Coviello and McAuley, 1999; Coviello and Munro, 1997; Fillis, 2001; Hohenthal, 2001 in Jansson and Sandberg, 2008) and that more research on mode should be devoted to these firms (Burgel and Murray, 2000; Laufs and Schwens, 2014; Zacharakis, 1997) that are characterised having "lack of resources, sensitivity to external challenges, special ownership structure" [Laufs and Schwens, (2014), p.1124].

The lack of focus on export-oriented MEs is a problem as they remain the industrial backbone of most European countries and a crucial driver of internationalisation and economic development (Kutlina-Dimitrova et al., 2018). Entry mode is a vital aspect of any internationalisation and especially for exporting MEs (Laufs and Schwens, 2014; Lu, 
2002; Schellenberg et al., 2018). Controlling or reducing costs of selling goods through various entry modes is a major objective for any market entry strategy. The choice of mode has implications for resource allocation and use, control and monitoring procedures, risks and liabilities and future options for expansion (Anderson and Gatignon, 1986; Hill et al., 1990). In short, entry mode choice is an important strategic decision for ME exporters and may evolve with varying external and internal conditions (Agarwal and Ramaswami, 1992; Zeriti et al., 2014).

Contrary to the small entrepreneurial firms, MEs typically have ample experience with internationalisation including markets in developing countries. In these contexts, considerations regarding modes supporting different entry strategies may be fundamentally dissimilar to those of 'developed/mature markets' due to their characteristics, such as relatively small purchasing power, high barriers to entry, and substantial government involvement in all aspects of society (Amankwah-Amoah et al., 2018; Cavusgil et al., 2002; Hansen et al., 2017). Developing markets are also characterised by harbouring several market failures, i.e., information problems, misguided regulation, and inefficient judicial systems (Amankwah-Amoah et al., 2018; Barrett et al., 2017; Cavusgil et al., 2002). Despite the MEs sizeable experience in internationalisation such markets pose stern challenges to them in terms of a higher degree and higher transactions costs (Khanna and Palepu, 1997; Rottig, 2016).

The purpose of this study is to explore European MEs' entry modes into challenging business environments in developing countries as experienced by 14 Danish MEs' attempts to export to Kenya. In this regard this study poses the following research question:

"What explains medium-sized enterprises' evolving entry mode choices in challenging business environments?"

The article is organised as follows: first, based on the extant literature, we will develop a model to predict the entry mode choice of MEs into challenging business environments. This model is, secondly, applied to an examination of 14 MEs' efforts to enter the Kenyan market and assess the extent to which the model can predict their entry modes. Thirdly, various explanations for the deviation and corroboration of the model are suggested. Lastly, we discuss implications of the findings for the literature and propose avenues for future research.

\section{Literature review and theoretical model}

In the following, we will propose a model of the evolution in MEs' choice of entry modes in challenging business environments. Based on Cuervo-Cazurra et al. (2018), we argue that entry mode decisions in challenging business environments are best understood in the dynamic interface of firm resources and the institutional environment (Hoskisson et al., 2000). Theoretically we will combine the resource-based perspective and the institutional perspective with a dynamic perspective based on a recently extended version of the Uppsala internationalisation process model (Dow et al., 2018b; Johanson and Vahlne, 1977). 


\subsection{The resource-based perspective}

It is well established from several studies that market entry modes can be partly explained by the resource-based view (RBV) (Lindsay et al., 2017; Meyer et al., 2009). Resource are understood as "all assets, capabilities, organisational processes, firm attributes, information, knowledge, etc.” [Barney, (1991), p.101]. RBV seeks, in essence, to explain how firms achieve a defendable and long-term advantageous competitive position through their accumulation of costly-to-copy resources (Barney, 1991; Peteraf, 1993; Wernerfelt, 1984). International market expansion, according to this view, is rooted in slack managerial, financial and production resources, and RBV can assist in understanding export performance (Bortoluzzi et al., 2014; Dhanaraj and Beamish, 2003; Leonidou et al., 2010). The focus on slack resources has been augmented by studies on how internationalisation allows firms to seize new opportunities and access complementary resources, notwithstanding that firms' propensity to export is partially stymied by resource constraints as they lack key resources (Assadinia et al., 2019; Nam et al., 2018).

The RBV has implications for an ME's entry mode: first, MEs may lack critical resources for higher commitment modes, such as stationing managers at sales subsidiaries for extended periods of time (Baum et al., 2015; Calof, 1994; Xie and Suh, 2014). This has implications for their internationalisation paths, which will tend to be muted and slow (Brouthers and Nakos, 2004, 2005). Second, resource constrained firms will adopt entry modes that allow them to access needed complementary resources, e.g., local distribution channels or information about consumer preferences. Complementary resources often cannot be purchased in the market due to their intangibility (Meyer et al., 2009) and their bundling with location-specific factors (Hennart, 2009), so exporters will need to establish contractual or even equity-based partnerships. Third, networks to related and supporting industries are according to recent theories of internationalisation viewed as $\mathrm{S}$ key to success. The business network theory argues that entry mode is profoundly shaped by the need to overcome outsidership in networks and become insiders (Jansson and Sandberg, 2008; Johanson and Vahlne, 2009; Vahlne and Ivarsson, 2014). Fourth, some resources will be particularly relevant to the choice of entry mode. Some MEs may be able to adopt high commitment entry modes, such as fully controlled subsidiaries or acquisitions if they have prior strong international experience (Brouthers and Nakos, 2004). Finally, the higher the commitment mode adopted by the exporter, the higher the exposure of the exporting firm and the greater the repercussions if the operation fails (Laufs and Schwens, 2014).

\subsection{The institutional perspective}

In order to conceptualise challenging business environments and the accompanying transaction costs, we use the institutional strategy perspective, i.e., the perspective that argues that we need to explicate business context in strategy analysis (Kostova et al., 2008; Peng et al., 2009). Hence, it is a commonly held view that the particular institutional context of developing markets affects entry mode (Adeola et al., 2018; Holtbrügge and Baron, 2013; Meyer et al., 2009). A previous study found that "relationships between well-established direct effects on entry mode choice are contingent on the institutional context" [Schwens et al., (2011), p.347], and for instance, 
in challenging business environments, institutional voids create high transaction costs (Khanna and Palepu, 1997, 2010; Rottig, 2016).

Transaction cost economics is the preeminent theory used to explain entry mode (Brouthers and Hennart, 2007; Canabal and White, 2008; He et al., 2016; Nydam Wulff, 2016). The idea of TC theory is that the intensity of export mode depends on the TC, i.e., bargaining, information, and enforcement costs of contracts with agents, distributors or joint venture partners. The literature on TC can assist in understanding how uncertainty related to institutional distance impacts entry mode (Cheng and Yu, 2008; Dow et al., 2018a; Erramilli and D'Souza, 1995), as well as how the experience of MEs from previous internationalisation may assist them in circumventing uncertainty in developing markets (Laufs and Schwens, 2014).

The effectiveness and nature of formal and informal institutions, described as 'rules of the game' [North, (1990), p.3], are of particular importance in developing countries (Chen et al., 2017; Meyer et al., 2009; Peng, 2014). In some developing countries, institutions straightforwardly dictate entry mode by stipulating the extent to which foreign firms need local partnerships. Judicial and other institutions determine the extent to which contracts can be enforced and thereby the feasibility of contractual entry modes such as agents and distributors. As MEs are more vulnerable to institutional voids than larger MNCs (Lu, 2002), the mode choice's ability to circumvent such voids becomes particularly important. It has been argued that high commitment modes better allow MEs to deal with the institutional voids of developing markets (Brouthers and Nakos, 2004).

\subsection{The internationalisation process perspective}

The Uppsala internationalisation process model (Uppsala model) suggests that insufficient knowledge is the primary hindrance for firms deciding to enter foreign markets and that internationalisation is facilitated by the acquisition of knowledge by being present in the foreign market (Johanson and Vahlne, 1977). The Uppsala model has been extended by the original authors to include a perspective on the role of networks in internationalisation (Johanson and Vahlne, 2003), an extension that introduces the concept of 'liability of outsidership' into the new network perspective (Johanson and Vahlne, 2009) and an account of how firm internationalisation evolves over time (Vahlne and Johanson, 2013).

A recent response to calls to emphasise the processual aspect of the Uppsala model added 'inertia' and 'managerial intentionality' (Dow et al., 2018b; Welch et al., 2016). The extended model addresses the conundrum of factors outside the original Uppsala model, which plays a substantial role in determining firms' resource commitments across borders (Pedersen and Petersen, 1998): organisational inertia stems from resistance to making necessary changes, and studies have found that dominant assumptions may be the result of "a web of self-reinforcing narratives" [Geiger and Antonacopoulou, (2009), p.432], and "resistance to change might emerge - constraining their ability to respond to the external environment" [Dow et al., (2018b), p.475]. The notion of inertia is interesting from the perspective of this article, as we explore entry mode preference from a dynamic perspective. Inertia in organisations originates from opposition to change, and "it means that organisations respond relatively slowly to the occurrence of threats and opportunities in their environment" [Hannan and Freeman, (1984), p.151] and must thus be understood in relative terms, as it describes the endeavour to preserve 'status quo' relative to changes in the environment. The fact that an organisation has a high level of 
inertia in one context does not imply high inertia in a different context (Hannan and Freeman, 1984; Stanczyk-Hugiet et al., 2017). This corresponds with the central notion that previous experience increases the probability of change (Cyert and March, 1963), and this means that limited experience in a specific context is likely to increase inertia. Inertial forces in organisations are, hence, stronger when MEs are planning to enter markets where they have limited, if any, experience.

\subsection{Toward a model for explaining export supporting entry modes in MEs}

In the following, we will develop a dynamic model for explaining what modes $\mathrm{ME}$ exporters will adopt given changing perceptions of resource strength and institutionally introduced transaction cost. We focus on modes aimed at export of products to foreign markets and do not consider local production to substitute export as MEs typically will produce niche products that cannot economically support several production sites.

\subsection{A contingency model for entry modes}

The export supporting modes typically presented by the literature span from simple arms-length transactions and over contractual modes to internalised modes (Welch et al., 2007) see Table 1.

Table 1 Entry modes

\begin{tabular}{lcccc}
\hline $\begin{array}{l}\text { Pure market } \\
\text { entry }\end{array}$ & Contractual entry & $\begin{array}{c}\text { Joint venture } \\
\text { (equity) }\end{array}$ & Acquisition & Fully controlled \\
\hline Export & $\begin{array}{c}\text { Franchise, agent } \\
\text { or distributor }\end{array}$ & $\begin{array}{c}\text { Sales and } \\
\text { service JV }\end{array}$ & $\begin{array}{c}\text { Acquisition of sales } \\
\text { and service } \\
\text { organisation }\end{array}$ & $\begin{array}{c}\text { Sales and service } \\
\text { subsidiary }\end{array}$ \\
\hline
\end{tabular}

Direct exporting can either be ongoing export to market or, as is typically the case, occasional exporting, for instance of capital goods. Direct exports take place through direct contact between customers and seller and through visits by an export manager. Contractual entries can be agents or distributors, and the difference is that the distributor entry modes require substantial investments by the distributor in inventory and the ability to provide sales-related services and advise (Reid, 1983). Equity-based entries can be fully controlled sales subsidiaries, joint ventures or acquisitions, e.g., of distributors.

In the model, entry mode choice is seen as determined by the interaction of two factors, namely firm internal capabilities and resources (e.g., managerial and financial resources, internationalisation experience, market knowledge) and business environment variables, including TC (e.g., determined by IPR protection, intangibility, frequency, institutional voids, and asset specificity).

Hence, we predict that, essentially, four entry modes are relevant to MEs:

- Direct export: In this case, we have low TC and high resources of the foreign firm.

Resource-rich firms may save resources in cases where TC are low by entering directly through direct exports. This mode will, however, often need substantial experience and resources from the foreign firm to identify and manage sales without a permanent market presence. This will typically be seen in cases of one-off 
high-value sales where a highly specialised export manager will be able to organise and implement the sale directly to the customer.

- Agents: In this case, we have low TC and low resources simultaneously: if the TC are very low - e.g., in cases of sales of standardised products with few IPR concerns - and the ME has limited resources and experience, a licence arrangement would be preferable. However, TC considerations such as IPR risks or lack of competent licensees may prevent this mode, and the exporter will opt for an agent. An agent is a low cost, low commitment mode and requires little more than sending products when the agent has received orders. It is, though, often difficult for MEs to align the interests with the agent, and the MEs retain the customer transaction risk.

- Distributors: In this case, we have high TC and low resources simultaneously. In challenging business environments, the exporter needs a committed and competent partner to circumvent the market and institutional barriers of the host country. Entering into challenging business environments with limited resources implies a strong reliance on external resources, and, therefore, the entry will take place through a distributor. This partner must have local networks and be willing and able to invest in building the distributorship. The downside of this strategy is a high reliance on the external partner and, hence, risks of opportunism. As a consequence of the risk of opportunism, the ME may take an equity stake in the distributor, making it a joint venture. And eventually, the ME may acquire the distributor, making it a sales subsidiary.

- Fully controlled sales subsidiaries: In this case, we have high TC and high resources simultaneously. Resource-rich firms may be able to circumvent high TC deriving from the nature of the transaction (e.g., high asset specificity) and the business environment (e.g., an ill-intentioned contract environment or uncertain market regulation) by entering through a $100 \%$ controlled sales and service subsidiaries. In both cases, this mode requires exporters with long-term internationalisation experience in similar regions and continued and robust engagement by the firm management in establishing the subsidiary.

In accordance with reviewed theory, we posit that the choice of mode for an ME is evolving over time. Hence, we add a dynamic process dimension based on the revised Uppsala model where we posit that an ME's planned entry mode evolves over time as the knowledge of the location changes and as experience is acquired. We will divide the entry mode decision process into three stages: aspirational stage, planning stage, and decision stage. The aspirational stage is where the export location is entering the radar of the firm, and it starts making more detailed enquiries regarding the market. This stage is characterised by limited knowledge of the market, including lack of knowledge of the precise nature of the liabilities of foreignness and outsidership that will be particularly high in challenging business environments. Hence, it can be expected that at this stage the considered entry mode is strongly informed by experience with mode selection in previous internationalisations supplemented with readily available information of market conditions, e.g., based on political and macro-economic factors. The Planning Stage is where the firm is moving toward a final decision. This stage is based on better knowledge of the business environment, i.e., the ME moves from more or less loose perceptions of the business environment toward a more informed understanding of the business environment in relation to their capabilities. It can, in accordance with the Uppsala 
model, be expected that the psychic distance at this stage is reduced as the firm moves from preliminary and rather superficial knowledge about the market to a deeper knowledge of the market conditions in its specific segment. The decision stage is where the firm makes the actual decision as to what mode to adopt. This is where top decision makers in the firm decide how much resources should be committed to enter the location and whom to partner up with. At the decision stage, it is possible that the ME has obtained knowledge about the difficulties of the location that makes it abandon the entry altogether.

We will assess the extent to which the model, Figure 1, can be employed to explain the entry mode of exporters at different phases of the entry process.

Figure 1 Entry mode model

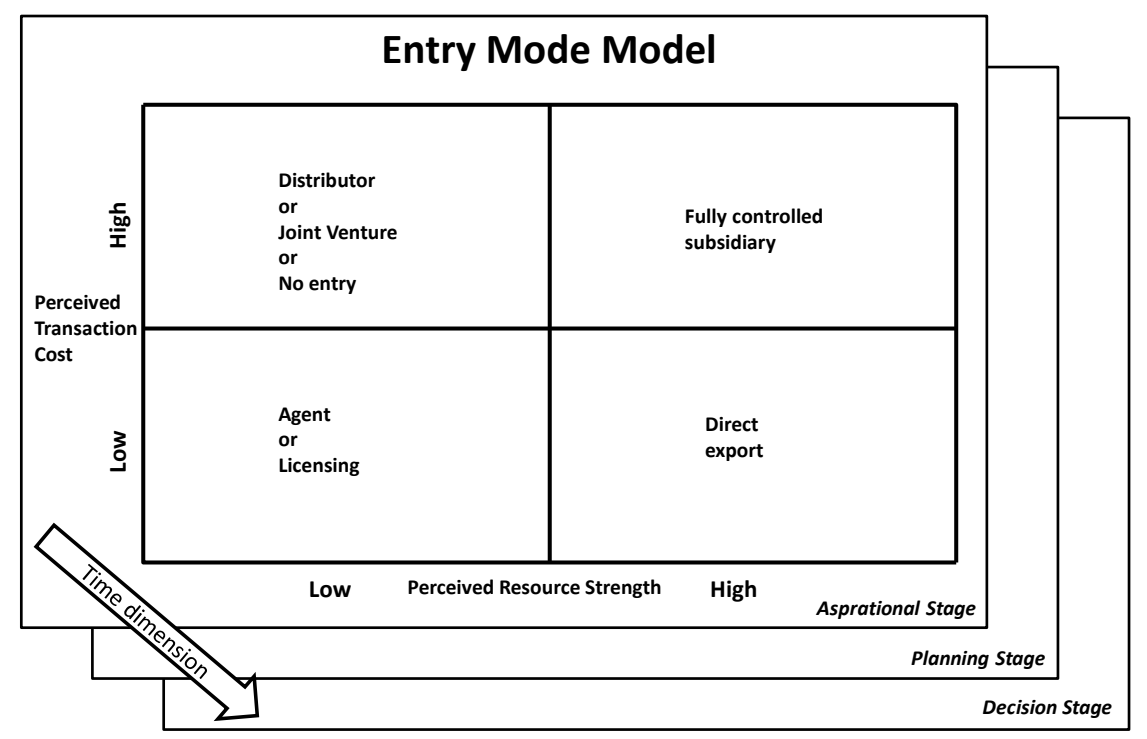

\section{Methodology, research context and cases}

\subsection{Methodology}

We adopted a 'laboratory setup' longitudinal multi-case approach (Miles and Huberman, 1994; Yin, 2014) to investigate MEs' decisions about market entry into Kenya. In this article, we exclude only the largest and most highly resourced multi-national enterprises by adopting a German definition of MEs to include gehobener Mittestand firms with a turnover up to EUR 1 billion (Fear et al., 2015). We focussed on 14 Danish MEs that were taking part in an export promotion project from June 2016 to June 2018 entitled 'Project Africanisation - from Naestved to Nairobi' undertaken by the Confederation of Danish Industry with an aim to explore "how MEs can be assisted in overcoming the challenges deriving from a combination of limited internal resources and a highly difficult African business environment" [Hansen and Gundelach, (2018), p.15]. The participating MEs shared the following four characteristics: 
1 all MEs were located in the same home country, i.e., Denmark

2 all cases were long established manufacturers

3 all cases had considerable IB experience

4 all had limited experience in export to East Africa (see Table 2).

All case MEs were visited during the summer of 2016 (one, case L, by telephone and one, case F, off-site), and the managers responsible for export were interviewed ('Interview - 2016'). These interviews were semi-structured, and they formed part of the general project initiation process. All interviews were conducted in English. The interviews were audio-recorded and transcribed, and the interview guide is in Appendix 1.

In addition, three sets of questionnaires were answered during the project:

1 at the start of the aspirational stage in August 2016

2 during the planning stage in June 2017

3 at the end of the decision stage in June 2018.

The questionnaires encompassed a range of project-related issues as well as questions explicitly directed at matters related to market entry decision, see Appendix 2. The questions were divided into the two categories reflected in our framework, i.e., perceived institutionally introduced transaction cost and perceived resource strength in order to place each ME in the x-y grid. All answers to the questionnaires were scored on a 5-point Likert scale and summed up. This procedure yielded $\mathrm{x}-\mathrm{y}$ grid positions for all MEs for the three stages, e.g., Figure 3, with the exception of cases M, F and I at the aspirational, planning and decision stages respectively due to missing positioning data.

Based on the theoretical framework and guided by the 2016 interview and the questionnaire data, we developed a codebook, see Appendix 3, to direct our qualitative data analysis (Bazeley and Jackson, 2013; Blaikie, 2010). The codebook framed the interview guide for the final semi-structured telephone interview ('Interview - 2018'), and the interviews were conducted with all case MEs in August and September 2018. The interviews were conducted in English and lasted about 45 minutes. To facilitate the interviews with practitioners, a non-theoretical jargon was used, e.g., TC was termed 'ease of doing business', and RBV was termed 'firm strength and advantages relative to the market'. The interview guide is included, and we refer to Appendix 4 for a complete list of questions.

\subsection{Case presentations}

The 14 MEs in the sample are far from start-ups, as the youngest firm is around 20 years old. In terms of industry, the firms are overwhelmingly in machinery and equipment, the exception being four firms that are engaged in food and beverage ingredients and two in electronics. "The companies are typically specialised producers that export a majority of their products because the Danish home market does not have the size to support sufficient sales" [Hansen and Gundelach, (2018), p.14]. They operate in BtB markets and, to a lesser extent, B-t-G markets, and none are directly engaging with consumers. All the firms are highly experienced exporters, typically with a minimum $85 \%$ export share of total sales. Some operate mainly in nearby markets, but most have experience 
from economically, culturally, administratively and geographically distant markets, including from Africa in most cases. Some of the MEs had limited prior experience in Kenya too.

Table 2 Overview of cases

\begin{tabular}{lcccccc}
\hline $\begin{array}{l}\text { Case } \\
\text { letter }\end{array}$ & Industry & $\begin{array}{c}\text { Firmage } \\
\text { in years }\end{array}$ & $\begin{array}{c}\text { Size (t/o in } \\
\text { mill. } \\
\text { EUR) }\end{array}$ & $\begin{array}{c}\text { Export } \\
\text { part in } \\
\text { pct.) }\end{array}$ & $\begin{array}{c}\text { Sub-Sahara } \\
\text { Africa } \\
\text { experience }\end{array}$ & $\begin{array}{c}\text { Kenya } \\
\text { experience }\end{array}$ \\
\hline A & Food ingredients & $>100$ & 225 & $50-85 \%$ & No & No \\
B & Machinery & $50-100$ & 70 & $85-100 \%$ & Yes & Yes \\
C & Machinery & $>100$ & 110 & $85-100 \%$ & Yes & Yes \\
D & Machinery & $>100$ & 285 & $85-100 \%$ & No & No \\
E & Food ingredients & $25-50$ & 70 & $25-50 \%$ & Yes & No \\
F & Electronics & $50-100$ & N/A & $50-85 \%$ & No & No \\
G & Machinery & $25-50$ & 125 & $85-100 \%$ & No & No \\
H & Food ingredients & $>100$ & 170 & $85-100 \%$ & Yes & Yes \\
I & Machinery & $>100$ & 500 & $50-85 \%$ & Yes & No \\
J & Machinery & $25-50$ & 35 & $85-100 \%$ & Yes & Yes \\
K & Machinery & $50-100$ & 700 & $85-100 \%$ & Yes & Yes \\
L & Electronics & $50-100$ & 85 & $85-100 \%$ & Yes & Yes \\
M & Machinery & $>100$ & 17 & $85-100 \%$ & Yes & Yes \\
N & Food ingredients & $0-25$ & 10 & $85-100 \%$ & Yes & Yes \\
\hline
\end{tabular}

Figure 2 Institutional distance - Sub-Saharan Africa

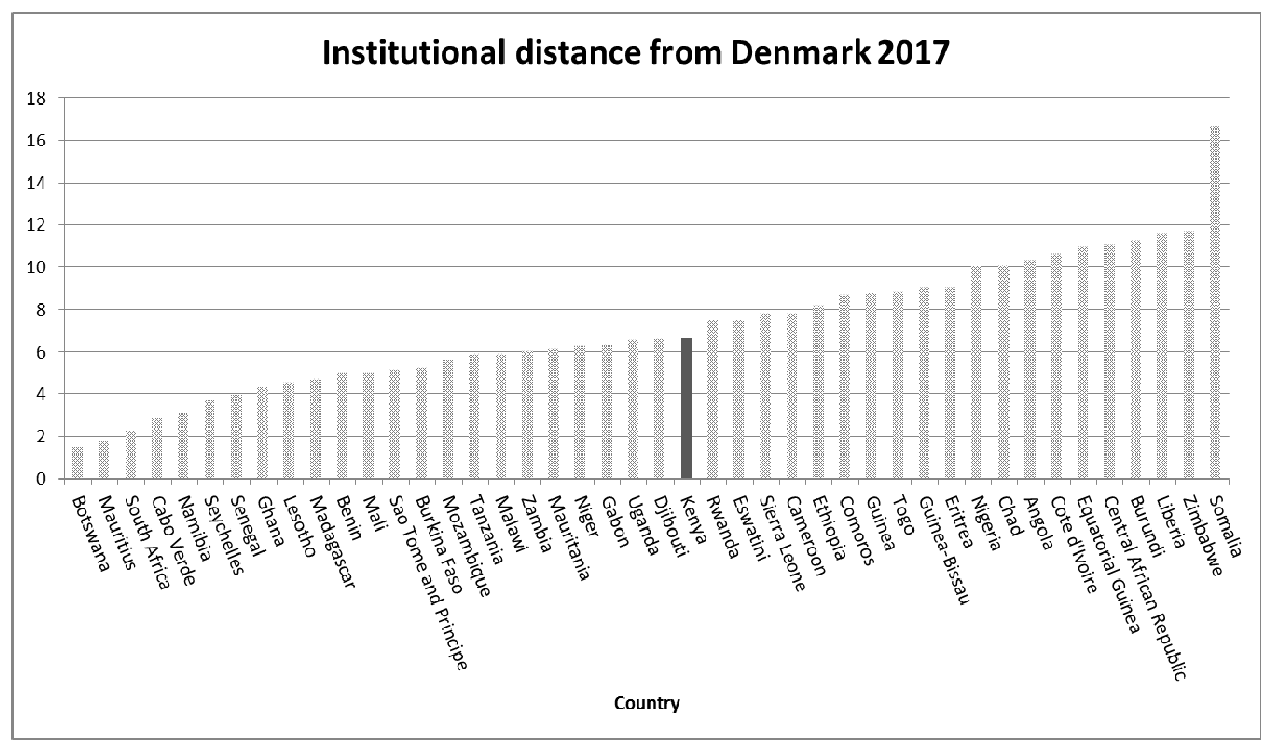




\subsection{Research context}

Kenya currently enjoys considerable economic growth and is seen by many as an essential business hub for the East-African market. Kenya has a population of about 48 mill. on an area of 580,000 sq. km., and a gross national income (GNI) per capita was reported at USD3,100 (2016 PPP), which places Kenya in the lower-middle-income group (The World Bank, 2017). The domestic economy (GDP per capita) grew 2.3\%, which compares favourably with Sub-Saharan Africa at $0.3 \%$ and a global average of $1.5 \%$ (The World Bank, 2017). In contrast to the somewhat encouraging economic and geographical statistics for Kenya, the challenging business environment stems from poor positions in IB rankings. The 'ease of doing business' index places it at 80th position (The World Bank, 2019b) mainly due to difficulties in public bureaucracy. The International Corruption Perception Index positions Kenya at an unenviable 143rd among the 180 counties surveyed (Transparency International, 2018). The institutional distance from Denmark is calculated by the commonly used composite index (Kogut and Singh, 1988), and it leaves Kenya as the 143rd furthest from Denmark (Kaufmann et al., 2011; The World Bank, 2017). The Sub-Saharan African countries are generally far from Denmark in institutional terms, and Kenya is placed in the middle, see Figure 2.

\section{Empirical findings}

\subsection{Aspirational stage}

All MEs were intrigued by the potentials of the East African market at project start, i.e., the high growth rates and the improving business environment. Based on the promises of the market and informed by their previous experience, all participating MEs had considerable prior export experience including some from Africa, see Table 2, and the MEs began the project by considering how they should enter Kenya. The two most frequent aspirational entry modes were to enter by appointing a distributor or to establish a subsidiary. The subsidiaries were mainly envisaged as sales and support offices and only in one case as a production facility (case C). The remaining four MEs expected to enter the Kenyan market by lower commitment modes, see Figure 3.

Cases $\mathrm{C}$ and $\mathrm{N}$ had some prior Kenyan experience and perceived their resource position to be among the highest of the MEs. Case $\mathrm{N}$ predicted a change in Kenyan consumer preference due to their re-engagement with the market. The MEs' opinions in terms of contract enforcement, protection of patents and IP-rights, and commercial transparency (TC position) were nevertheless different, and case $\mathrm{N}$ perceived it at the highest level. Cases K and B's opinion about their resource position was relatively lower, whereas case K's TC position was based on previous unsuccessful experiences: “... but you need somebody who can actually import goods and do this in a proper way." Case B operates in business-to-government market and payment was a considerable issue: "The Ministry of [deleted], very difficult for ... payment."

The remaining ten MEs with less or no prior Kenyan business experience were diverse in their resource positions and TC positions, and two of the MEs with the most substantial resource positions expected to establish subsidiaries in Kenya, see Figure 3. Case $\mathrm{H}$ stated that its "high quality and certified products will lead to [sought after] food safety", and case L felt confident in being "the only supplier who is certified [within our 
line of business]." Both firms acknowledged high TC positions at market entry. The views on this point were more diverse for cases J, D and I, who considered resource and market environmental compatibility to be high. Case J sold high-value machinery and planned to appoint an agent and enter into operating lease-arrangements with their final customers. Case J considered its TC position improved by using non-Kenyan financial instruments. In comparison case D and I did perceive their TC positions higher, and case $\mathrm{D}$ indicated a requirement for a buy-out clause in their agency contract due to the business risk involved, "... if we do not have the option to, later on, take the (agency) $100 \%$, we will say 'thank you very much'."

Figure 3 Positions at the aspirational stage

\section{MEs' perceived transaction cost and resource positions at aspirational stage}

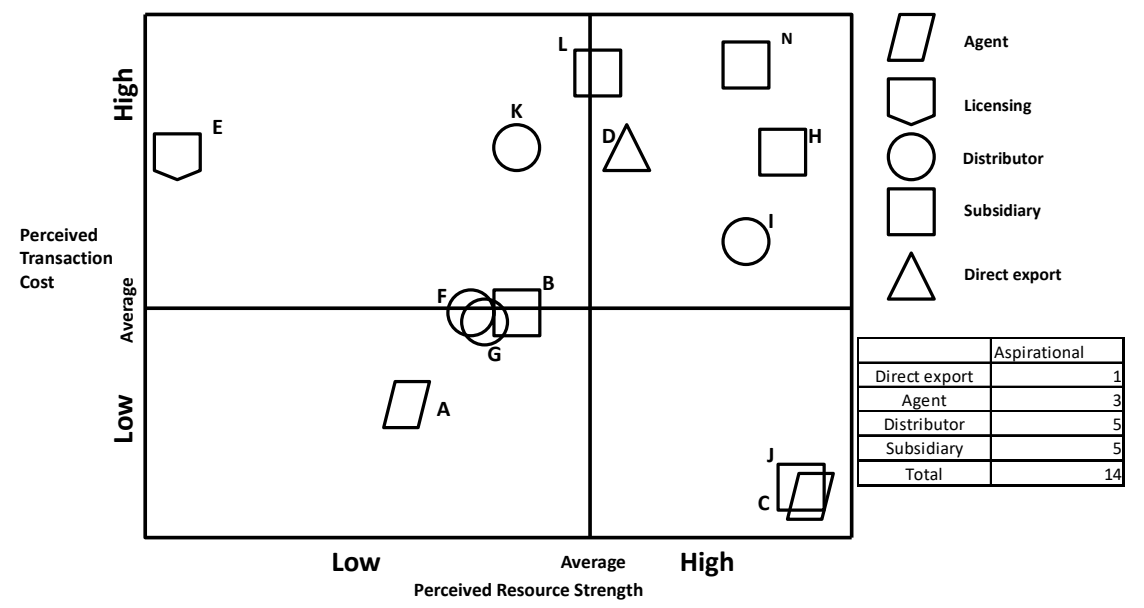

Case $\mathrm{F}$ related their anticipated $\mathrm{TC}$ to their operation in other challenging business environments, e.g., Russia, Moldova and China; as their export manager said, "We saw some of the same challenges in China. Yes, it is difficult." Case G wanted to offset their medium resource position with strong local presence: "we need very strong support in Africa if we want to succeed ... it was a distributor we wanted to have", and case A envisaged a two-stage market approach by initially appointing an agent and later establish local joint-venture production: "We do it with an agent, which is what we are used to do and have quite good successes around. Another option is to do some kind of joint venture ... (later)." A leading supplier within the B-t-G market (case B) envisaged from the outset to establish a subsidiary "as support to our partners or distributors". In essence, none of the four cases foresaw 'going it alone' and planned different modes of entry.

Two MEs perceived high TC positions and low resource positions (cases K and E) at the beginning of the project, and one of the MEs is an exporter of highly specialised food ingredients (case E), and due to strict Kenyan Government regulations, it perceived at the outset its resource position as the lowest. The ME's management was concerned, despite a substantial market potential, with its limited HQ resources to establish sufficiently large-scale distribution. Concerns over IPR protection caused Case E furthermore to a 
high TC position, as stated by management: "It concerns us a lot. How we can protect our IP rights."

In summary, 5 of 14 MEs expected at the outset to establish a subsidiary, 5 expected to establish a distributorship, and the remainder to enter through low commitment modes, agents or licensees. Three MEs who were highly resourced and also expected high TCs planned initially for establishing subsidiaries in line with the predictive model (cases $\mathrm{N}$, $\mathrm{H}$, and L).

\subsection{Planning stage}

Most MEs were engaged in selecting local business partners in Kenya at the planning stage one year into the project, and only three firms were 'undecided' at this stage. The experience in the Kenyan marked had dampened the MEs' view of their resource strength, and several firms changed also their perception of TCs and their envisaged mode of entry, see Figure 4.

Figure 4 Positions at the planning stage

\section{MEs' perceived transaction cost and resource positions} at planning stage

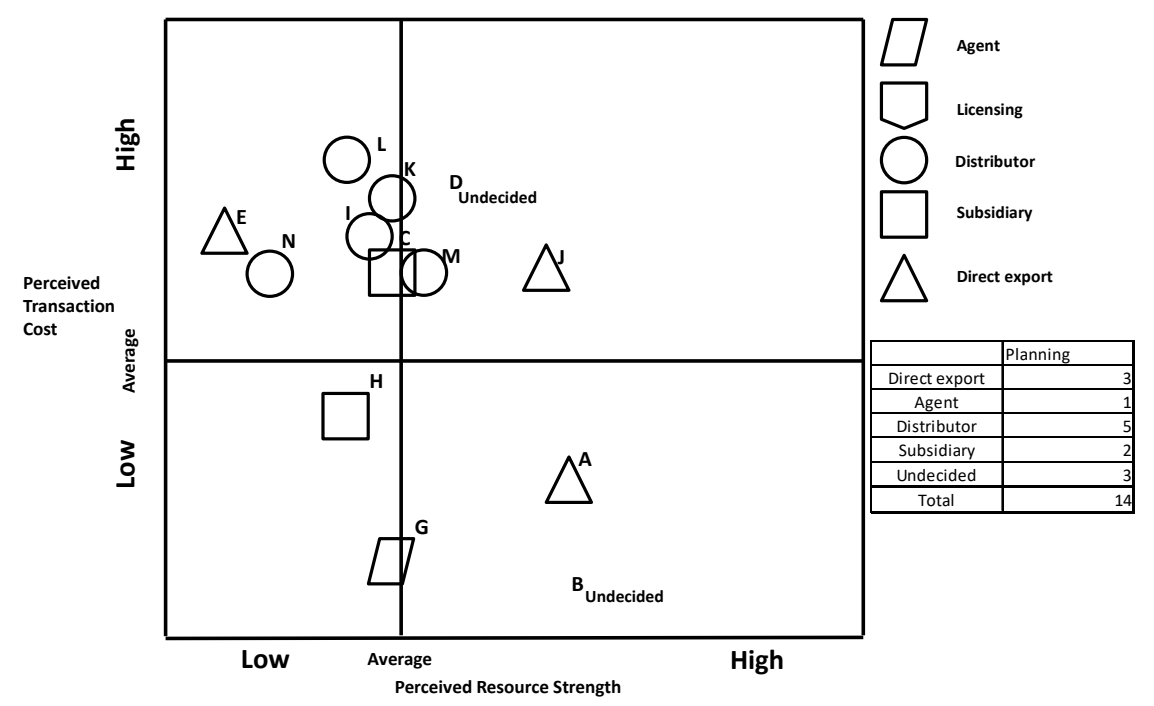

Case $\mathrm{J}$ viewed, at the aspirational stage, the Kenyan market to be quite undemanding and that its superior technology would pave the way for an uncomplicated entry. The export manager for case J also saw that market as 'bigger than expected'. This ME did, however, realise that Chinese competitors had secured a strong foothold with very able local distributors forcing case $\mathrm{J}$ to alter its preferred entry to direct export to selected large customers. One firm downgraded its aspiration from establishing a subsidiary to export its food ingredients (case N) through distributors and only establish a small local service office as a back-up. Case $\mathrm{N}$ also realised that its assessment at the aspirational stage of resource strength vis-à-vis the Kenya market was overstated and adjustments to its assortment were necessary. It realised, however, that the market potential was bigger than 
envisaged, and to reap the rewards it had to change its entry mode: "We have to change our normal way of doing things" as the general manager for Africa stated. Case I also saw a large potential for its machines, and it decided to move the responsibility for East Africa from its HQ export department to its subsidiary in South Africa. Case K remained relatively unchanged in its view of its market potential, but it found that product transport for its heavy machinery to be complicated, time-consuming and costly; and "a very low level of local knowledge" about its technology added to a slow market entry. Case E had changed its favoured entry mode to direct export of alternative products as its main product was unsuitable. "We had to give up exporting [confidential] due to Kenyan legislation" (case E). One ME was frustrated by long delays and changed its favoured mode of entry from subsidiary to export via a distributor, and the responsible manager stated "The general election in Kenya, and a lack of foreign currency are used as excuses for the delay" (case L). The general view of the MEs at the planning stage was

a the market potential in Kenya was bigger than expected

b they themselves were less resource strong in comparison with the local competition

c it was necessary to be flexible regarding mode of entry.

Despite the positive market outlook, none of the MEs stated a desire to augment their mode commitment in entering the Kenyan market, and in contrast, eight firms expressed views to commit to lower commitment entry modes, see Table 3.

\subsection{Decision stage}

Before the decision stage of the project, three MEs had decided against market entry into Kenya. Case A had realised that the entry points into Kenya were limited and that the level of non-transparent business practices left them too uncomfortable to operate in the market. Case D stated that "the market was [simply] too small", and case L had a change of corporate strategy and "gave lower priority to [its] activities in Africa." Two MEs assessed, however, their resources at a comparatively higher level, and case $\mathrm{J}$ found that the appointment of a new agent gave them additional resource in the market. Case $\mathrm{H}$ had first considered a sales subsidiary, but after realising the market potential, and "customers' readiness for change", it enhanced its local resources by establishing a distribution facility in Kenya.

The four remaining MEs were still pursuing the Kenyan market, but after two years of activity in the Kenyan market, they anticipated a resource shortfall nevertheless. Case $\mathrm{G}$ had found a positive opening in the market, but they suffered from a shortage of staff to intensify visits to the market. Case B had augmented its knowledge-base but saw a resource deficit due to an inability to enlarge its local network. They stated that overall demand on internal resources hindered further expansion. Case $\mathrm{M}$ found a relevant market opening but with fewer and longer-term entry points than expected. The export manager accepted the MEs inability to develop an Africa tailor-made market approach, and this slowed its market entry down. The three non-pursuant MEs regarded their TC perception at the highest and almost equal level (cases A, F and L), see Figure 5, whereas six of the seven still Kenya active MEs saw it highly equal. Only one ME deviated from this view, and case N saw TCs at a lower level. All actual entry modes are depicted in Figure 5 . 
Table 3 Change of entry mode

\begin{tabular}{|c|c|c|c|c|c|}
\hline Case & $\begin{array}{l}\text { Entry mode- } \\
\text { aspirational }\end{array}$ & $\begin{array}{l}\text { Entry mode - } \\
\text { planning }\end{array}$ & $\begin{array}{c}\text { Change of } \\
\text { commitment from } \\
\text { aspirational to } \\
\text { planning stage }\end{array}$ & $\begin{array}{l}\text { Entry mode } \\
\text { - decision }\end{array}$ & $\begin{array}{c}\text { Change of } \\
\text { commitment from } \\
\text { aspirational to } \\
\text { decision stage }\end{array}$ \\
\hline A & Agent & Direct export & Lower & No entry & Lower \\
\hline B & Subsidiary & Undecided & Lower & Distributor & Lower \\
\hline $\mathrm{C}$ & Subsidiary & Subsidiary & Same & Subsidiary & Same \\
\hline $\mathrm{D}$ & Direct export & Undecided & Lower & No entry & Lower \\
\hline $\mathrm{E}$ & Agent & Direct export & Lower & No entry & Lower \\
\hline $\mathrm{F}$ & Distributor & Undecided & Lower & No entry & Lower \\
\hline G & Distributor & Agent & Lower & Agent & Lower \\
\hline $\mathrm{H}$ & Subsidiary & Subsidiary & Same & Subsidiary & Same \\
\hline I & Distributor & Distributor & Same & No entry & Lower \\
\hline $\mathrm{J}$ & Agent & Direct export & Lower & Agent & Same \\
\hline K & Distributor & Distributor & Same & Distributor & Same \\
\hline $\mathrm{L}$ & Subsidiary & Distributor & Same & No entry & Lower \\
\hline M & Distributor & Distributor & Same & Distributor & Same \\
\hline $\mathrm{N}$ & Subsidiary & Distributor & Lower & Subsidiary & Same \\
\hline \multicolumn{4}{|c|}{ Change of entry mode from aspirational to decision stage } & \multicolumn{2}{|c|}{ Frequency } \\
\hline \multicolumn{4}{|l|}{ Yes } & \multicolumn{2}{|r|}{2} \\
\hline \multicolumn{4}{|l|}{ No } & \multicolumn{2}{|r|}{6} \\
\hline \multicolumn{3}{|c|}{ Abandon } & & \multicolumn{2}{|r|}{6} \\
\hline \multicolumn{2}{|l|}{ Total } & & & \multicolumn{2}{|r|}{14} \\
\hline \multicolumn{2}{|c|}{ Entry mode } & Aspirational & \multicolumn{2}{|l|}{ Planning } & Decision \\
\hline \multicolumn{2}{|c|}{ Direct export } & 1 & \multicolumn{2}{|l|}{3} & 0 \\
\hline \multicolumn{2}{|c|}{ Agent } & 3 & \multicolumn{2}{|l|}{1} & 2 \\
\hline \multicolumn{2}{|c|}{ Distributor } & 5 & \multicolumn{2}{|l|}{5} & 3 \\
\hline \multicolumn{2}{|c|}{ Subsidiary } & 5 & \multicolumn{2}{|l|}{2} & 3 \\
\hline \multicolumn{2}{|c|}{ Undecided } & 0 & \multicolumn{2}{|l|}{3} & 0 \\
\hline \multicolumn{2}{|c|}{ No entry } & 0 & \multicolumn{2}{|l|}{0} & 6 \\
\hline \multicolumn{2}{|l|}{ Total } & 14 & 14 & & 14 \\
\hline
\end{tabular}

In comparison with the MEs initial entry aspirations in August 2016, six MEs decided to abandon a Kenyan market entry, and of the remainder, in fact only two of the eight entered by their aspirational mode, as can be seen in Table 3. The early expectations about Kenyan market entry were for four of the MEs founded without previous Kenyan experience. The inexperienced MEs entered Kenya via distributorships in cases G, J, and $\mathrm{M}$, and $\mathrm{H}$ as a subsidiary. The four MEs were involved in different industries, and their resource strength was at both the aspirational and decision stages higher for cases $\mathrm{J}$ and $\mathrm{H}$ and lower for cases $\mathrm{G}$ and $\mathrm{M}$. Their TC perceptions were initially varied but quite similar at the end of the project. Of the remaining three with previous Kenyan experience, there was only a change of entry mode in case B, which down-graded its entry from 
establishing a subsidiary to remaining with its initial agent by stating “... establishing a subsidiary is not abandoned, but not implemented [yet]."

Figure 5 Positions at the decision stage

\section{MEs' perceived transaction cost and resource positions at decision stage}

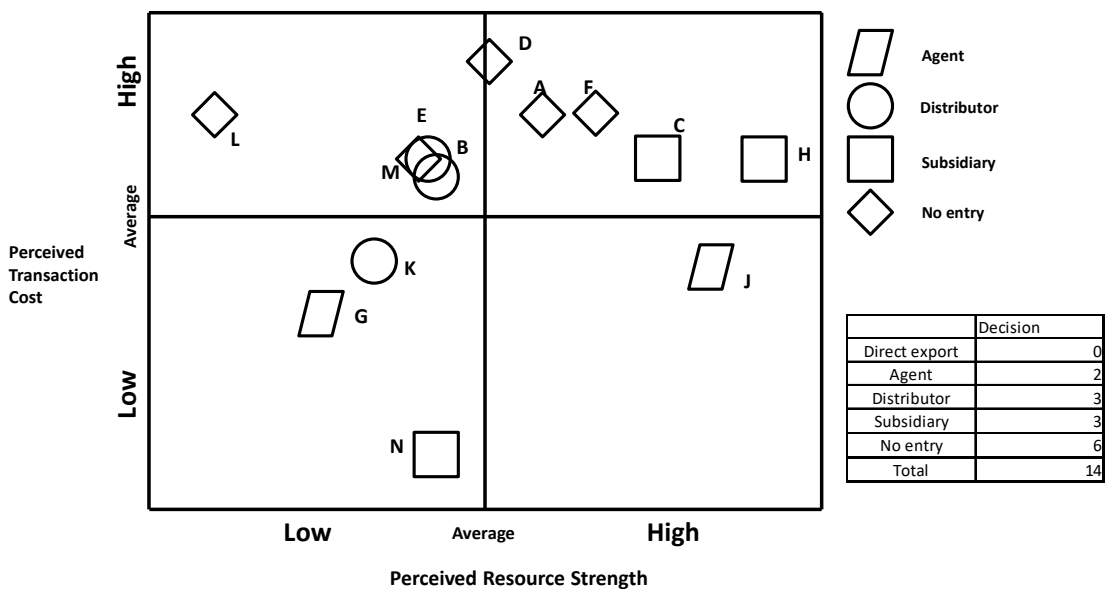

\subsection{How do MEs' entry mode considerations evolve?}

Already at the outset, we observe there are remarkable differences between the MEs initial expectations prior to entry and their actual entry modes. All 14 MEs commenced, whether they had previous Sub-Sahara African experience or not with 'high hopes', but only 8 of 14 MEs entered the Kenyan market, notwithstanding sporadic export activities. The six MEs which decided against entry, of which two had previous market experience, were divided equally between higher and lower commitment aspirational entry modes. These MEs decided against market entry due to change of strategic direction (cases E, F, I and L), postponement (case D), and transparency issues (case A).

During the aspirational stage, the MEs' assessed that they had a strong resource positions coupled with relatively deep concerns about the challenging business environment. The MEs' positions are shown marked in Figure 6, which depicts the aspirational, planning and decision stages as well as the movement of the average position. As the MEs started gaining more specific knowledge about the Kenyan market through study trips to Kenya and several workshops, they changed their impression of their resource and TC positions considerably. The MEs' positions are marked in Figure 6 and show a reduced resource position at the Planning stage indicating that the MEs had gained insights in the Kenyan market resulting in a more moderate impression of their strengths in the market. Some MEs observed the maturity of the Kenyan market, such as "I did not expect there were so many bigger companies, industries in the area" (case H), and "in the start of the project, we thought we knew it all, but we needed to learn some more" (case B). Some MEs' changed their impression of only one of the two perspectives, e.g., cases D and L who had a high, but relatively unchanged, view of TC, and in line with most MEs changed their resource strength downwards and later ended as 
non-entrants. Case A, who already at the mid-term stage decided against market entry "it became colder and colder in terms of me pushing to get any business currently in the Kenya market." This ME had an unchanged view of their resource position, but they had had market experiences that changed their TC positions considerably.

Figure 6 Movement of positions during the stages

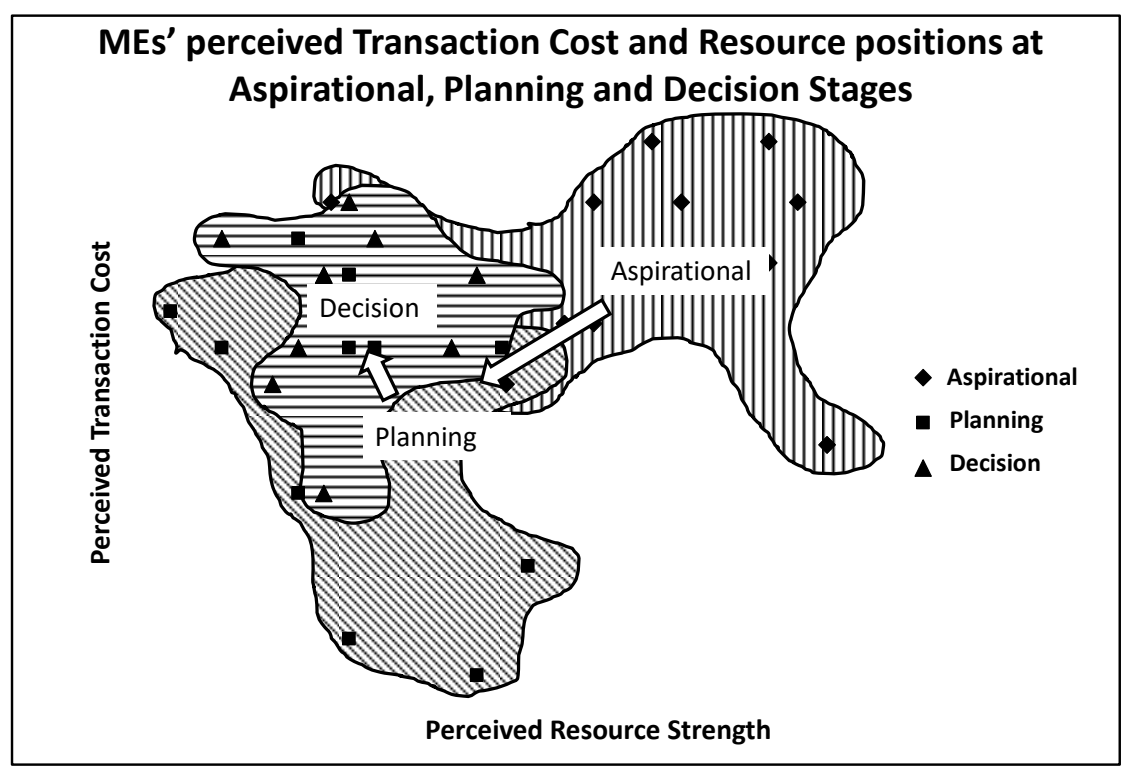

After gaining further market information and experience in Kenya, all MEs, except case A, perceived their resource positions to be lower than initially observed in relation to market entry. Two main resource constraints were stated by some MEs. First, several MEs mentioned missing accurate market information and local insights, and second, access to local networks was a significant resource deficit. The difficulty of obtaining reliable market statistics was expressed by case $G$ “... we need market details ... and that is what we have been chasing for more than half a year ... moreover, we did not get it", and case B recognised the need to "network is more important than initially assumed." The difference in culture, and particularly the perception of speed and time, caused several MEs to accede a resource deficit leading to a need to change their 'standard operating procedure' in relation to the Kenyan market. Case L said “... much longer time than in our own culture", and case B stated, "meeting culture and [adherence to] deadlines are much different than in Europe." The views were summed up by case N saying "The entry to the market is not as expected. We have to change away from our usual 'new market entry' procedure." Case $\mathrm{N}$ did not, in contrast to their statement, change their entry mode. Contrary to the increase in perceived resource deficits, the MEs generally viewed the TC position to be more positive than initially expected. The newly acquired insights about the 'Kenyan way to do business' reduced the level of uncertainty for most of the MEs. One export manager, case H, found that it was "surprisingly easy and inexpensive to establish a subsidiary in Kenya, and the necessary [legal] institutions are here already." 
Despite a considerable shift in the export manager's assessment of their resource and TC positions, their initially planned entry mode was changed only in two cases during the project. Case H noted, that "(we) want to have subsidiaries, the market is strategic ... and this is the normal way"; case C "I would say it is the (our) way"; case M "for basically (all) our markets, we work through a distributor"; case A "we ship directly ... we do it primarily with agents"; case D "what we do at the moment is from Europe ... travel out from Europe"; and case $\mathrm{N}$ "that is sort of always been (our) strategy ... we are trying to keep the same way of procedure for selling." Only two cases noted that their planned entry mode changed, as "it depends (on) which markets" (case J), and "there is no real standard approach because every market is different" (case K).

The MEs had accumulated considerable experience and knowledge about the Kenyan market during the two years they were surveyed, but this led to mainly one of two outcomes: either the MEs generally maintained their aspirational entry mode, or they abandoned the market entry altogether. This leads us to assert that increasing experience and a higher level of information about the Kenyan market did not change the MEs' entry mode. On the contrary, decision makers entrenched back into their aspirational entry mode suggesting a high degree of inertia. The entry mode decision was in six of the eight entry cases in line with the MEs' expected choice of entry mode. Two MEs changed their entry mode during the project. Hence, the perception of optimal entry mode did not change over time despite the ME acquiring a more profound knowledge of the location. In a total of 8 of 14 cases did the MEs, for a variety of reasons, deem their planned mode of entry unsuitable, and this led to a no-entry decision in six cases, as shown in Table 3. This makes us deduce that forces of inertia reduce the ME's adjustment of its mode of entry into challenging business environments in spite of growing specific knowledge about its own resources in relation to the difficult business environment. In the cases where behavioural adjustments were made as MEs gained a more realistic understanding of internal and external contingencies, it was mainly in the form of decisions not to enter.

\section{Discussion}

This study set out to develop a model to examine the evolution in MEs' choice of entry modes in the search for export opportunities in the challenging business environment of Kenya. A first contribution was that our model for predicting entry mode choice in challenging business environments proved useful. It was demonstrated that ME entry mode decision could be understood as a dynamic fit (Zajac et al., 2000) between firm resources, capabilities and paths in lieu of institutionally related TC. Hence, this study demonstrated that entry mode choice is a dynamic process where MEs over time are changing their perceptions of their own resources and business environment factors.

The study took place in a setting where ME exporters were followed over two years and asked about their expected entry mode in Kenya in lieu of their perceived resources and their impression of location challenges. Over the two years, the MEs had ample opportunity to acquire knowledge about the market and to adopt a more realistic and informed entry mode decision. Several intriguing insights in relation to the literature on experiential learning and psychic distance were provided via this study.

One of the founding tenets of the classical Uppsala internationalisation process model is that resource commitment increases as experiences are gained and the negative 
perception of risk diminishes (Erramilli, 1991; Johanson and Vahlne, 1990, 1977). In this perspective, it is interesting to observe that the MEs' risk perception over the two-year period, as witnessed by their TC positions, in general, returned to its higher level after two years, see Figure 6, whereas the MEs' view of their resource strength vis-à-vis the market shifted downwards during the two-year period. The implication is that psychic distance is not a linear variable where more knowledge about a location causes more confidence in the location, but on the contrary, as they gain experience, MEs may build an increasingly realistic understanding that there is no fit between their resources and the location, leading to an abandonment of entry altogether. Moreover, where the Uppsala model depicts entries in terms of incremental adjustments toward increasingly higher commitment entry modes, the actual behaviour of MEs in challenging business environments is more one of binary choices, entry as either originally planned or no entry at all.

A key insight in relation to the literature concerns inertia. According to theories of internationalisation, MEs will accumulate knowledge and experience and thus alter their strategies accordingly (Hill et al., 1990; Johanson and Vahlne, 1977; Reid, 1983), and that this is of particular importance in the challenging business environments in emerging economies and developing countries (Meyer et al., 2009; Neuland and Hough, 2010; Wright et al., 2005). However, as argued, the MEs entering Kenya did not, in general, alter their entry mode considerations in the course of the two years. Hence, it appears that there is substantial inertia in entry mode decisions. The implication for literature on entry mode is that inertia in an internationalisation process perspective should be explicated in explanatory models. Thereby, our findings offer valuable insights to the structural inertia theory (Hannan and Freeman, 1984; Kelly and Amburgey, 1991) which forms the basis for the conceptualisation of inertia (Dow et al., 2018b). In theory, structural inertia will either lead to 'new structure' or 'failure' [Kelly and Amburgey, (1991), p.593].

A final insight is that experiential learning mainly is related to entry/no entry decisions. In this study, the failure rate is very high; even with 14 firms all initially highly committed to entering Kenya, almost half decided not to enter at all. This is somewhat surprising, as entry mode theory states that firms have a range of options available, and based on their acquired knowledge they will, albeit limited by bounded rationality, select the most appropriate entry mode among these multiple modes. The multiple available modes, and MEs' allegedly wanting to grow should, thus, lead MEs to enter the Kenyan market. Our finding was that 6 of 14 MEs abandoned entry contrary to the Uppsala internationalisation process model. Given the limited sample size, it can tentatively be suggested that the results may be due to the limited market size in Kenya in combination with the MEs' internal resource constraints or that the MEs may simply have given higher priority to other markets and product areas with a higher return of investment. Hence, the conclusion is that over time, firms do not move toward a greater willingness to commit to the market, but they become more clarified whether or not they should enter as they discover the difficulties of the location and the opportunity costs of entry. In other words, experiential learning is mainly associated with the binary choice of entry/ non-entry, not the actual entry mode.

Based on our study of the MEs' attempt to establish a strong position to export to Africa we thus make four significant theoretical contributions: 
1 Entry mode strategy in challenging business environments can be meaningfully analysed as a dynamic fit between firms' own resources, capabilities and paths in lieu of institutional factors.

2 'Psychic distance' is not, as otherwise implied by the Uppsala model, reduced with time and experience but may on the contrary increase over time as MEs become more aware of business environment challenges and internal resource constraints and the combination of those.

3 Contrary to experiential learning thinking, firms are reluctant to change entry mode in view of more specific information about the business environment in combination with their firm-specific resources and capabilities. This confirms the inertia theory advanced by, among others (Dow et al., 2018b).

4 However, experiential learning takes place, but it overwhelmingly concerns the binary choice of entry/no entry. The implication for theory is that the learning perspective should be applied to a higher degree to entry decisions rather than mode decisions.

\section{Conclusions, limitations and further research}

This study set out to explore the entry modes adopted by MEs seeking export to Africa. The existing literature on firms' entry modes appears to be concentrated on either resource-rich MNEs or resource constrained SMEs, whereas there is a lacuna in the recent IB literature on MEs' entry modes in general, and in challenging business environments in particular. A two-year longitudinal study of 14 MEs provided data about the perceived transaction costs and resource strength positions of the MEs as well as their planned and actual entry modes into the Kenyan market.

This study found that the MEs shifted their view of their resource strength downwards, whereas their perception of transaction cost remained at a high level. The two most favoured aspirational entry modes were high commitment modes, i.e., to establish subsidiaries or to enter via a distributor. Only four MEs expected to enter via lower commitment modes. After two years, the situation was completely different from what had been anticipated: two MEs decided to enter the Kenyan market utilising a different actual mode of entry, and, more importantly, six MEs decided to abandon entry altogether. Hence, MEs appear to have abandoned entry rather than modify entry mode in light of changing perceptions of their own resources considering local business environment factors. Our interpretation of these findings is that inertial forces within the MEs lead to the abandonment of entry as a substitute for change of entry mode. It thus appears that MEs in highly challenging business environments do not want to experiment with their proven business model. While they thereby, in many ways, play it safe, their lack of willingness to engage in organisational experimentation and innovation also means the MEs may potentially forego lucrative business opportunities. The findings of the study corroborate recent theoretical arguments that conventional internationalisation process models need to include inertia as a key explanant of entry mode choice.

The context specificity and the limited number of case firms that formed the empirical foundation for this study require further empirical research of this important topic in order to verify the findings and conclusions. This study gained rarely achieved 
access to a cross selection of companies during their simultaneous market entry process. The interviews with the managers provided ample insights into the market entry process. Nonetheless, the findings of this study have some limitations. Albeit some of the findings of this study may be transferred to other contexts, one needs to exert caution when generalising from a limited number of case studies. Additional research based in a different context could assist in uncovering further aspects of the market entry processes, and thereby provide a solid foundation for generalisation across settings. Further qualitative research may also validate the findings of this study by replication and develop testable hypotheses. A quantitative test of such hypotheses using cross-sectional and/or longitudinal data could provide further insights into the associations between firms' resources and capabilities and their entry mode strategies in lieu of business environment factors and unearth hitherto unknown interaction effects.

\section{References}

Adeola, O., Boso, N. and Adeniji, J. (2018) 'Bridging institutional distance: an emerging market entry strategy for multinational enterprises', in Agarwal, J. and Wu, T. (Eds.): Emerging Issues in Global Marketing, pp.205-230, Springer International Publishing AG, Cham, Switzerland.

Agarwal, S. and Ramaswami, S.N. (1992) 'Choice of foreign-market entry mode - impact of ownership, location and internalization factors', Journal of International Business Studies, Vol. 23, No. 1, pp.1-27.

Amankwah-Amoah, J., Debrah, Y.A. and Nuertey, D. (2018) 'Institutional legitimacy, cross-border trade and institutional voids: insights from the Cocoa Industry in Ghana', Journal of Rural Studies, Vol. 58, pp.136-145.

Anderson, E. and Gatignon, H. (1986) 'Modes of foreign entry - a transaction cost-analysis and propositions', Journal of International Business Studies, Vol. 17, No. 3, pp.1-26.

Assadinia, S., Boso, N., Hultman, M. and Robson, M. (2019) 'Do export learning processes affect sales growth in exporting activities?', Journal of International Marketing, Vol. 27, No. 3, pp.1-25.

Barney, J. (1991) 'Firm resources and sustained competitive advantage', Journal of Management, Vol. 17, No. 1, pp.99-120.

Barrett, C.B., Christiaensen, L., Sheahan, M. and Shimeles, A. (2017) 'On the structural transformation of rural Africa', Journal of African Economies, Vol. 26, No. suppl_1, pp.i11-i35.

Baum, M., Schwens, C. and Kabst, R. (2015) 'A latent class analysis of small firms' internationalization patterns', Journal of World Business, Vol. 50, No. 4, pp.754-768.

Bazeley, P. and Jackson, K. (2013) Qualitative Data Analysis with Nvivo, 2nd ed., Sage Publications Ltd., London, England.

Blaikie, N. (2010) Designing Social Research, 2nd ed., Polity Press, Cambridge, UK.

Bortoluzzi, G., Chiarvesio, M., Di Maria, E. and Tabacco, R. (2014) 'Exporters moving toward emerging markets: a resource-based approach', International Marketing Review, Vol. 31, No. 5, pp.506-525.

Brouthers, K.D. and Hennart, J-F. (2007) 'Boundaries of the firm: insights from international entry mode research', Journal of Management, Vol. 33, No. 3, pp.395-425.

Brouthers, K.D. and Nakos, G. (2004) 'SME entry mode choice and performance: a transaction cost perspective', Entrepreneurship Theory and Practice, Vol. 28, No. 3, pp.229-247.

Brouthers, L.E. and Nakos, G. (2005) 'The role of systematic international market selection on small firms' export performance', Journal of Small Business Management, Vol. 43, No. 4, pp.363-381. 
Buckley, P.J. and Casson, M.C. (1998) 'Analyzing foreign market entry strategies: extending the internalization approach', Journal of International Business Studies, Vol. 29, No. 3, pp.539-561.

Burgel, O. and Murray, G.C. (2000) 'The international market entry choices of start-up companies in high-technology industries', Journal of International Marketing, Vol. 8, No. 2, pp.33-62.

Calof, J.L. (1994) 'The relationship between firm size and export behavior revisited', Journal of International Business Studies, Vol. 25, No. 2, pp.367-387.

Canabal, A. and White, G.O. (2008) 'Entry mode research: past and future', International Business Review, Vol. 17, No. 3, pp.267-284.

Cavusgil, S.T., Ghauri, P.N. and Agarwal, M.R. (2002) Doing Business in Emerging Markets: Entry and Negotiation Strategies, SAGE Publications, Inc., Thousands Oaks, CA, USA.

Chen, R., Cui, L., Li, S. and Rolfe, R. (2017) 'Acquisition or greenfield entry into Africa? Responding to institutional dynamics in an emerging continent', Global Strategy Journal, Vol. 7, No. 2, pp.212-230.

Cheng, H-L. and Yu, C-M.J. (2008) 'Institutional pressures and initiation of internationalization: evidence from Taiwanese small- and medium-sized enterprises', International Business Review, Vol. 17, No. 3, pp.331-348.

Coviello, N. and McAuley, A. (1999) 'Internationalisation and the smaller firm: a review of contemporary empirical research', Management International Review, Vol. 39, No. 3, pp.223-256.

Coviello, N. and Munro, H. (1997) 'Network relationships and the internationalisation process of small software firms', International Business Review, Vol. 6, No. 4, pp.361-386.

Cuervo-Cazurra, A., Mudambi, R. and Pedersen, T. (2018) 'The boundaries of the firm in global strategy', Global Strategy Journal, Vol. 8, No. 2, pp.211-219.

Cyert, R.M. and March, J.G. (1963) A Behavioral Theory of the Firm, 1st ed., Prentice Hall, Inc., Englewood Cliffs, New Jersey, USA.

Dansk Industri (2016) Afrikas Muligheder - Set i Dansk Perspektiv, The Danish Industry Foundation and Confederation of Danish Industry, Copenhagen, Denmark.

Davis, P.S., Desai, A.B. and Francis, J.D. (2000) 'Mode of international entry: an isomorphism perspective', Journal of International Business Studies, Vol. 31, No. 2, pp.239-258.

Dhanaraj, C. and Beamish, P.W. (2003) 'A resource-based approach to the study of export performance', Journal of Small Business Management, Vol. 41, No. 3, pp.242-261.

Dow, D., Baack, D. and Parente, R. (2018a) 'The role of psychic distance in entry mode decisions: magnifying the threat of opportunism or increasing the need for local knowledge?', Global Strategy Journal, pp.1-26, forthcoming.

Dow, D., Liesch, P. and Welch, L. (2018b) 'Inertia and managerial intentionality: extending the Uppsala model', Management International Review, Vol. 58, No. 3, pp.465-493.

Erramilli, M.K. (1991) 'The experience factor in foreign market entry behavior of service firms', Journal of International Business Studies, Vol. 22, No. 3, pp.479-501.

Erramilli, M.K. and D'Souza, D.E. (1995) 'Uncertainty and foreign direct investment: the role of moderators', International Marketing Review, Vol. 12, No. 3, pp.47-60.

Fear, J., Venohr, B. and Witt, A. (2015) 'Best of German Mittelstand - the world market leaders', in Langenscheidt, F. and Venohr, B. (Eds.): The Best of German Mittelstand: The World Market Leaders, pp.10-27, Deutsche Standards, Cologne, Germany.

Fillis, I. (2001) 'Small firm internationalisation: an investigative survey and future research directions', Management Decision, Vol. 39, No. 9, pp.767-783.

Geiger, D. and Antonacopoulou, E. (2009) 'Narratives and organizational dynamics - exploring blind spots and organizational inertia', The Journal of Applied Behavioral Science, Vol. 45, No. 3, pp.411-436. 
Getachew, Y.S. and Beamish, P.W. (2017) 'Foreign subsidiary exit from africa: the effects of investment purpose diversity and orientation', Global Strategy Journal, Vol. 7, No. 1, pp.58-82.

Hannan, M.T. and Freeman, J. (1984) 'Structural inertia and organizational change', American Sociological Review, Vol. 49, No. 2, pp.149-164.

Hansen, M.W. and Gundelach, H. (2018) Opportunities and Challenges for Danish Medium-Sized Exporters in Africa, The Danish Industry Foundation and Confederation of Danish Industry, Copenhagen, Denmark.

Hansen, M.W., Langevang, T., Rutashobya, L. and Urassa, G. (2017) 'Coping with the African business environment: enterprise strategy in response to institutional uncertainty in Tanzania', Journal of African Business, Vol. 19, No. 1, pp.1-26.

He, X., Lin, Z. and Wei, Y. (2016) 'International market selection and export performance: a transaction cost analysis', European Journal of Marketing, Vol. 50, Nos. 5/6, pp.916-941.

Hennart, J-F. (2009) 'Down with MNE-centric theories! Market entry and expansion as the bundling of MNE and local assets', Journal of International Business Studies, Vol. 40, No. 9, pp.1432-1454.

Hill, C.W.L., Hwang, P. and Kim, W.C. (1990) 'An eclectic theory of the choice of international entry mode', Strategic Management Journal, Vol. 11, No. 2, pp.117-128.

Holtbrügge, D. and Baron, A. (2013) 'Market entry strategies in emerging markets: an institutional study in the BRIC countries', Thunderbird International Business Review, Vol. 55, No. 3, pp.237-252.

Hoskisson, R.E., Eden, L., Lau, C.M. and Wright, M. (2000) 'Strategy in emerging economies', Academy of Management Journal, Vol. 43, No. 3, pp.249-267.

Jansson, H. and Sandberg, S. (2008) 'Internationalization of small and medium sized enterprises in the Baltic Sea Region', Journal of International Management, Vol. 14, No. 1, pp.65-77.

Johanson, J. and Vahlne, J.E. (1977) 'The internationalization process of the firm - a model of knowledge development and increasing foreign market commitments', Journal of International Business Studies, Vol. 8, No. 1, pp.23-32.

Johanson, J. and Vahlne, J.E. (2003) 'Business relationship learning and commitment in the internationalization process', Journal of International Entrepreneurship, Vol. 1, No. 1, pp.83-101.

Johanson, J. and Vahlne, J-E. (1990) 'The mechanism of internationalisation', International Marketing Review, Vol. 7, No. 4, pp.11-24.

Johanson, J. and Vahlne, J-E. (2009) 'The Uppsala internationalization process model revisited: from liability of foreignness to liability of outsidership', Journal of International Business Studies, Vol. 40, No. 9, pp.1411-1431.

Kaufmann, D., Kraay, A. and Mastruzzi, M. (2011) 'The worldwide governance indicators: methodology and analytical issues', Hague Journal on the Rule of Law, Vol. 3, No. 2, pp.220-246.

Kelly, D. and Amburgey, T.L. (1991) 'Organizational inertia and momentum: a dynamic model of strategic change', The Academy of Management Journal, Vol. 34, No. 3, pp.591-612.

Khanna, T. and Palepu, K. (1997) 'Why focused strategies may be wrong for emerging markets', Harvard Business Review, July-August, Vol. 75, No. 4, pp.41-51.

Khanna, T. and Palepu, K. (2010) Winnng in Emerging Markets - A Road Map for Strategy and Execution, Harvard Business School Publishing, Boston, Mass., USA.

Kogut, B. and Singh, H. (1988) 'The effect of national culture on the choice of entry mode', Journal of International Business Studies, Vol. 19, No. 3, pp.411-432.

Kostova, T. (1999) 'Transnational transfer of strategic organizational practices: a contextual perspective', Academy of Management Review, Vol. 24, No. 2, pp.308-324. 
Kostova, T. and Zaheer, S. (1999) 'Organizational legitimacy under conditions of complexity: the case of the multinational enterprise', Academy of Management Review, Vol. 24, No. 1, pp.64-81.

Kostova, T., Roth, K. and Dacin, M.T. (2008) 'Institutional theory in the study of multinational corporations: a critique and new directions', Academy of Management Review, Vol. 33, No. 4, pp.994-1006.

Kutlina-Dimitrova, Z., Rueda-Cantuche, J.M., Amores, A.F. and Roman, M.V. (2018) Chief Economist Note: How Important are EU Exports for Jobs in the EU?, European Commission, Bruxelles, Belgium.

Laufs, K. and Schwens, C. (2014) 'Foreign market entry mode choice of small and medium-sized enterprises: a systematic review and future research agenda', International Business Review, Vol. 23, No. 6, pp.1109-1126.

Leonidou, L.C., Katsikeas, C.S. and Coudounaris, D.N. (2010) 'Five decades of business research into exporting: a bibliographic analysis', Journal of International Management, Vol. 16, No. 1, pp.78-91.

Lindsay, V., Rod, M. and Ashill, N. (2017) 'Institutional and resource configurations associated with different SME foreign market entry modes', Industrial Marketing Management, Vol. 66, pp.130-144.

Lu, J.W. (2002) 'Intra- and inter-organizational imitative behavior: institutional influences on Japanese firms' entry mode choice', Journal of International Business Studies, Vol. 33, No. 1, pp.19-37.

Meyer, K.E., Estrin, S., Bhaumik, S.K. and Peng, M.W. (2009) 'Institutions, resources, and entry strategies an emerging economies', Strategic Management Journal, Vol. 30, No. 1, pp.61-80.

Miles, M.B. and Huberman, A.M. (1994) Qualitative Data Analysis, 2nd ed., SAGE Publications, Inc., Thousand Oaks, CA, USA.

Nam, J., Liu, X., Lioliou, E. and Jeong, M. (2018) 'Do board directors affect the export propensity and export performance of Korean firms? A resource dependence perspective', International Business Review, Vol. 27, No. 1, pp.269-280.

Neuland, E. and Hough, J. (2010) 'Key success factors for business operations in emerging markets: qualitative results from sub-Saharan Africa', Corporate Ownership and Control, Vol. 8, No. 1 E, pp.419-429.

North, D.C. (1990) Institutions, Institutional Change and Economic Performance, Cambridge University Press, Cambridge, England.

Nydam Wulff, J. (2016) 'A systematic assessment of empirical research on foreign entry mode', European Journal of Marketing, Vol. 50, Nos. 5/6, pp.942-972.

Pedersen, T. and Petersen, B. (1998) 'Explaining gradually increasing resource commitment to a foreign market', International Business Review, Vol. 7, No. 5, pp.483-501.

Peng, M.W. (2001) 'The resource-based view and international business', Journal of Management, Vol. 27, No. 6, pp.803-829.

Peng, M.W. (2014) 'New research directions in the institution-based view', Research in Global Strategic Management, Vol. 16, pp.59-78.

Peng, M.W., Sun, S.L., Pinkham, B. and Chen, H. (2009) 'The institution-based view as a third leg for a strategy tripod', Academy of Management Perspectives, Vol. 23, No. 3, pp.63-81.

Peteraf, M.A. (1993) 'The cornerstones of competitive advantage: a resource based view', Strategic Management Journal, Vol. 14, No. 3, pp.179-191.

Reid, S. (1983) 'Firm internationalization, transaction costs and strategic choice', International Marketing Review, Vol. 1, No. 2, pp.44-56.

Rottig, D. (2016) 'Institutions and emerging markets: effects and implications for multinational corporations', International Journal of Emerging Markets, Vol. 11, No. 1, pp.2-17.

Schellenberg, M., Harker, M.J. and Jafari, A. (2018) 'International market entry mode - a systematic literature review', Journal of Strategic Marketing, Vol. 26, No. 7, pp.601-627. 
Schwens, C., Eiche, J. and Kabst, R. (2011) 'The moderating impact of informal institutional distance and formal institutional risk on SME entry mode choice', Journal of Management Studies, Vol. 48, No. 2, pp.330-351.

Stanczyk-Hugiet, E., Piorkowska, K. and Stanczyk, S. (2017) 'Organizational routines and context alteration: a reconciliation', Argumenta Oeconomica, Vol. 39, No. 2, pp.341-371.

The World Bank (2017) World Development Indicators 2017, World Bank Group, Washington, DC, USA [online] http://databank.worldbank.org/data/home.aspx (accessed 10 April 2018).

The World Bank (2019a) The World Bank Worldwide Governance Indicators [online] https://info.worldbank.org/governance/wgi/\#home (accessed 30 June 2019).

The World Bank (2019b) Ease of Doing Business 2019 [online] https://www.doingbusiness.org/en/ reports/global-reports/doing-business-2019 (accessed 13 August 2019).

Transparency International (2018) Corruption Perceptions Index, Transparency International, Berlin, Germany [online] https://www.transparency.org/cpi2018 (accessed 2 August 2019).

Tvedten, K., Hansen, M.W. and Jeppesen, S. (2014) 'Understanding the rise of African business', African Journal of Economic and Management Studies, Vol. 5, No. 3, pp.249-268.

Vahlne, J.E. and Johanson, J. (2013) 'The Uppsala model on evolution of the multinational business enterprise - from internalization to coordination of networks', International Marketing Review, Vol. 30, No. 3, pp.189-210.

Vahlne, J-E. and Ivarsson, I. (2014) 'The globalization of Swedish MNEs: empirical evidence and theoretical explanations', Journal of International Business Studies, Vol. 45, No. 3, pp.227-247.

Welch, C., Nummela, N. and Liesch, P. (2016) 'The internationalization process model revisited: an agenda for future research', Management International Review, Vol. 56, No. 6, pp.783-804.

Welch, L.S., Benito, G.R.G. and Petersen, B. (2007) Foreign Operation Methods: Theory, Analysis, Strategy, Edward Elgar Publishing Ltd., Cheltenham, Glos., UK.

Wernerfelt, B. (1984) 'A resource-based view of the firm', Strategic Management Journal, Vol. 5, No. 2, pp.171-180.

Wright, M., Filatotchev, I., Hoskisson, R.E. and Peng, M.W. (2005) 'Strategy research in emerging economies: challenging the conventional wisdom - introduction', Journal of Management Studies, Vol. 42, No. 1, pp.1-33.

Xie, Y.H. and Suh, T. (2014) 'Perceived resource deficiency and internationalization of small- and medium-sized firms', Journal of International Entrepreneurship, Vol. 12, No. 3, pp.207-229.

Yin, R.K. (2014) Case Study Research - Design and Methods, 5th ed., SAGE Publications, Inc., Thousand Oaks, CA, USA.

Zacharakis, A.L. (1997) 'Entrepreneurial entry into foreign markets: a transaction cost perspective', Entrepreneurship Theory and Practice, Vol. 21, No. 3, pp.23-40.

Zaheer, S. (1995) 'Overcoming the liability of foreignness', The Academy of Management Journal, Vol. 38, No. 2, pp.341-363.

Zajac, E.J., Kraatz, M.S. and Bresser, R.K.F. (2000) 'Modeling the dynamics of strategic fit: a normative approach to strategic change', Strategic Management Journal, Vol. 21, No. 4, pp.429-453.

Zeriti, A., Robson, M.J., Spyropoulou, S. and Leonidou, C.N. (2014) 'Sustainable export marketing strategy fit and performance', Journal of International Marketing, Vol. 22, No. 4, pp.44-66. 


\section{Appendix 1}

'Interview - 2016' - interview guide

1 General interest in Africa

1.1 But if you just could, for today, wind the clock back to when you entered in to this project...

1.2 Why did you get engaged in this project?

1.3 Did the interest in East Africa (or increasing your turnover there) come out of a strategic plan or was it just ...?

2 Possible entry into Africa

2.1 And did you think about any other ways of getting more business in Africa rather than this project?

3 Prioritising Africa

3.1 Going into Africa takes it time and money; which other projects could be then pushed on the backburner now?

3.2 Was it only East Africa or ... what options did you consider?

3.3 Do you have any other countries (and in Africa) in mind?

4 Possible barriers to entry

4.1 And when you think about this project in Africa, what are the biggest obstacles?

4.2 Are there any things in Kenya, or is it also difficult to say because you do not know it in detail, but when you go into new areas of legislation, registration, IP protection and so on, is that an issue and how do you overcome that?

\section{Appendix 2}

Questionnaire at the beginning of the project-regarding TCs

\begin{tabular}{lccccc}
\hline $\begin{array}{l}\text { What hindrance and obstacles does the } \\
\text { firm see on the East African } \\
\text { market - missing protection of IP } \\
\text { rights }\end{array}$ & $\begin{array}{l}\text { Strongly } \\
\text { disagree }\end{array}$ & Disagree & $\begin{array}{c}\text { Neither } \\
\text { agree nor } \\
\text { disagree }\end{array}$ & $\begin{array}{c}\text { Agree } \\
\text { What hindrance and obstacles does the }\end{array}$ & $\begin{array}{c}\text { Strongly } \\
\text { agree }\end{array}$ \\
$\begin{array}{l}\text { firm see on the East African } \\
\text { market - local bureaucracy }\end{array}$ & $\begin{array}{l}\text { Strongly } \\
\text { disagree }\end{array}$ & Disagree & $\begin{array}{c}\text { Neither } \\
\text { agree nor } \\
\text { disagree }\end{array}$ & Agree & $\begin{array}{c}\text { Strongly } \\
\text { agree }\end{array}$ \\
$\begin{array}{l}\text { What hindrance and obstacles does the } \\
\text { firm see on the East African } \\
\text { market - corruption }\end{array}$ & $\begin{array}{l}\text { Strongly } \\
\text { disagree }\end{array}$ & Disagree & $\begin{array}{l}\text { Neither } \\
\text { agree nor } \\
\text { disagree }\end{array}$ & Agree & Strongly \\
agree
\end{tabular}




\section{Regarding $R B V$}

\begin{tabular}{|c|c|c|c|c|c|}
\hline $\begin{array}{l}\text { The firm's position in relation to the } \\
\text { East African market relies on unique } \\
\text { product(s)? }\end{array}$ & $\begin{array}{l}\text { Strongly } \\
\text { disagree }\end{array}$ & Disagree & $\begin{array}{l}\text { Neither } \\
\text { agree nor } \\
\text { disagree }\end{array}$ & Agree & $\begin{array}{c}\text { Strongly } \\
\text { agree }\end{array}$ \\
\hline $\begin{array}{l}\text { The firm's position in relation to the } \\
\text { East African market relies on strong } \\
\text { commitment from owner/top } \\
\text { management? }\end{array}$ & $\begin{array}{l}\text { Strongly } \\
\text { disagree }\end{array}$ & Disagree & $\begin{array}{l}\text { Neither } \\
\text { agree nor } \\
\text { disagree }\end{array}$ & Agree & $\begin{array}{c}\text { Strongly } \\
\text { agree }\end{array}$ \\
\hline $\begin{array}{l}\text { The firm's position in relation to the } \\
\text { East African market relies on a flexible } \\
\text { and adaptable organisation? }\end{array}$ & $\begin{array}{l}\text { Strongly } \\
\text { disagree }\end{array}$ & Disagree & $\begin{array}{l}\text { Neither } \\
\text { agree nor } \\
\text { disagree }\end{array}$ & Agree & $\begin{array}{c}\text { Strongly } \\
\text { agree }\end{array}$ \\
\hline $\begin{array}{l}\text { The firm's position in relation to the } \\
\text { East African market relies on } \\
\text { experience from other African } \\
\text { countries? }\end{array}$ & $\begin{array}{l}\text { Strongly } \\
\text { disagree }\end{array}$ & Disagree & $\begin{array}{l}\text { Neither } \\
\text { agree nor } \\
\text { disagree }\end{array}$ & Agree & $\begin{array}{c}\text { Strongly } \\
\text { agree }\end{array}$ \\
\hline $\begin{array}{l}\text { The firm's strength in elation to the } \\
\text { East African market is, that it can draw } \\
\text { on experience from other challenging } \\
\text { business environments? }\end{array}$ & $\begin{array}{l}\text { Strongly } \\
\text { disagree }\end{array}$ & Disagree & $\begin{array}{l}\text { Neither } \\
\text { agree nor } \\
\text { disagree }\end{array}$ & Agree & $\begin{array}{c}\text { Strongly } \\
\text { agree }\end{array}$ \\
\hline $\begin{array}{l}\text { The firm's strength in elation to the } \\
\text { East African market is, that it can draw } \\
\text { on strong sales - and marketing } \\
\text { resources? }\end{array}$ & $\begin{array}{l}\text { Strongly } \\
\text { disagree }\end{array}$ & Disagree & $\begin{array}{l}\text { Neither } \\
\text { agree nor } \\
\text { disagree }\end{array}$ & Agree & $\begin{array}{c}\text { Strongly } \\
\text { agree }\end{array}$ \\
\hline $\begin{array}{l}\text { The firm's strength in elation to the } \\
\text { East African market is, that it can draw } \\
\text { on strong financial resources? }\end{array}$ & $\begin{array}{l}\text { Strongly } \\
\text { disagree }\end{array}$ & Disagree & $\begin{array}{l}\text { Neither } \\
\text { agree nor } \\
\text { disagree }\end{array}$ & Agree & $\begin{array}{c}\text { Strongly } \\
\text { agree }\end{array}$ \\
\hline
\end{tabular}

Questionnaire at mid-term and end of the project-regarding TCS

\begin{tabular}{|c|c|c|c|c|c|}
\hline $\begin{array}{l}\text { What is the firm's opinion about the } \\
\text { importance of political matter in } \\
\text { business in East Africa? }\end{array}$ & $\begin{array}{l}\text { Strongly } \\
\text { agree }\end{array}$ & Agree & $\begin{array}{l}\text { Neither } \\
\text { agree nor } \\
\text { disagree }\end{array}$ & Disagree & $\begin{array}{l}\text { Strongly } \\
\text { disagree }\end{array}$ \\
\hline $\begin{array}{l}\text { What is the firm's opinion about the } \\
\text { extent of corruption and nepotism in } \\
\text { the market? }\end{array}$ & $\begin{array}{l}\text { Strongly } \\
\text { agree }\end{array}$ & Agree & $\begin{array}{l}\text { Neither } \\
\text { agree nor } \\
\text { disagree }\end{array}$ & Disagree & $\begin{array}{l}\text { Strongly } \\
\text { disagree }\end{array}$ \\
\hline $\begin{array}{l}\text { Does the firm witness unethical } \\
\text { business methods by its prospective } \\
\text { partners? }\end{array}$ & $\begin{array}{l}\text { Strongly } \\
\text { disagree }\end{array}$ & Disagree & $\begin{array}{l}\text { Neither } \\
\text { agree nor } \\
\text { disagree }\end{array}$ & Agree & $\begin{array}{c}\text { Strongly } \\
\text { agree }\end{array}$ \\
\hline $\begin{array}{l}\text { Does the firm withness } \\
\text { untransparent business relations with } \\
\text { its prospective partners? }\end{array}$ & $\begin{array}{l}\text { Strongly } \\
\text { disagree }\end{array}$ & Disagree & $\begin{array}{l}\text { Neither } \\
\text { agree nor } \\
\text { disagree }\end{array}$ & Agree & $\begin{array}{c}\text { Strongly } \\
\text { agree }\end{array}$ \\
\hline $\begin{array}{l}\text { Is it vital to the firm's business } \\
\text { posibilities that the local authorities } \\
\text { set standards and rules? }\end{array}$ & $\begin{array}{l}\text { Strongly } \\
\text { disagree }\end{array}$ & Disagree & $\begin{array}{l}\text { Neither } \\
\text { agree nor } \\
\text { disagree }\end{array}$ & Agree & $\begin{array}{c}\text { Strongly } \\
\text { agree }\end{array}$ \\
\hline
\end{tabular}




\section{Regarding $R B V$}

\begin{tabular}{|c|c|c|c|c|c|}
\hline $\begin{array}{l}\text { Is your firm's opinion about the East } \\
\text { African market that it is much easier } \\
\text { than anticipated? }\end{array}$ & $\begin{array}{l}\text { Strongly } \\
\text { agree }\end{array}$ & Agree & $\begin{array}{l}\text { Neither } \\
\text { agree nor } \\
\text { disagree }\end{array}$ & Disagree & $\begin{array}{l}\text { Strongly } \\
\text { disagree }\end{array}$ \\
\hline $\begin{array}{l}\text { Has your firm's opinion about its } \\
\text { 'value proposition' changed? }\end{array}$ & $\begin{array}{l}\text { Strongly } \\
\text { agree }\end{array}$ & Agree & $\begin{array}{l}\text { Neither } \\
\text { agree nor } \\
\text { disagree }\end{array}$ & Disagree & $\begin{array}{l}\text { Strongly } \\
\text { disagree }\end{array}$ \\
\hline $\begin{array}{l}\text { What has been or is important for } \\
\text { your firm's success - has it been } \\
\text { backing from owner/top } \\
\text { management? }\end{array}$ & $\begin{array}{l}\text { Strongly } \\
\text { disagree }\end{array}$ & Disagree & $\begin{array}{l}\text { Neither } \\
\text { agree nor } \\
\text { disagree }\end{array}$ & Agree & $\begin{array}{c}\text { Strongly } \\
\text { agree }\end{array}$ \\
\hline $\begin{array}{l}\text { What has been or is important for } \\
\text { your firm's success - has it been } \\
\text { finding the right people for the task } \\
\text { in your organisation? }\end{array}$ & $\begin{array}{l}\text { Strongly } \\
\text { disagree }\end{array}$ & Disagree & $\begin{array}{l}\text { Neither } \\
\text { agree nor } \\
\text { disagree }\end{array}$ & Agree & $\begin{array}{c}\text { Strongly } \\
\text { agree }\end{array}$ \\
\hline $\begin{array}{l}\text { What has been or is important for } \\
\text { your firm's success - has it been to } \\
\text { identify the right local business } \\
\text { partner? }\end{array}$ & $\begin{array}{l}\text { Strongly } \\
\text { disagree }\end{array}$ & Disagree & $\begin{array}{l}\text { Neither } \\
\text { agree nor } \\
\text { disagree }\end{array}$ & Agree & $\begin{array}{c}\text { Strongly } \\
\text { agree }\end{array}$ \\
\hline $\begin{array}{l}\text { What has been or is important for } \\
\text { your firm's success - has it been to } \\
\text { adapt your products to the market? }\end{array}$ & $\begin{array}{l}\text { Strongly } \\
\text { disagree }\end{array}$ & Disagree & $\begin{array}{l}\text { Neither } \\
\text { agree nor } \\
\text { disagree }\end{array}$ & Agree & $\begin{array}{c}\text { Strongly } \\
\text { agree }\end{array}$ \\
\hline $\begin{array}{l}\text { What has been or is important for } \\
\text { your firm's success - has it been to } \\
\text { adapt your prices to the market? }\end{array}$ & $\begin{array}{l}\text { Strongly } \\
\text { disagree }\end{array}$ & Disagree & $\begin{array}{l}\text { Neither } \\
\text { agree nor } \\
\text { disagree }\end{array}$ & Agree & $\begin{array}{c}\text { Strongly } \\
\text { agree }\end{array}$ \\
\hline $\begin{array}{l}\text { What has been or is important for } \\
\text { your firm's success - has it been to } \\
\text { have 'plain luck'? }\end{array}$ & $\begin{array}{l}\text { Strongly } \\
\text { disagree }\end{array}$ & Disagree & $\begin{array}{l}\text { Neither } \\
\text { agree nor } \\
\text { disagree }\end{array}$ & Agree & $\begin{array}{c}\text { Strongly } \\
\text { agree }\end{array}$ \\
\hline
\end{tabular}

\section{Appendix 3}

\section{Code book}

\section{RBV position}

\section{1 aspirational}

1.2 planning

1.3 decision.

\section{TC position}

2.1 aspirational

2.2 planning

2.3 decision. 
3 Entry mode

3.1 aspirational

3.2 planning

3.3 decision

3.4 lock of decision

3.5 level of decision making

3.6 no-entry.

4 Business partner approach

4.1 information

4.2 influence on decisions.

5 Personal opinion

5.1 'entry or no-entry'

5.2 over-ruled.

6 Staffing commitments and internal organisation.

7 Expectations and results.

\section{Appendix 4}

'Interview - 2018' - question guide

1 General entry question

1.1 We asked you in the questionnaire about your views on your firm's strengths and the 'ease of doing business in Kenya' (TC/resource framework): "how do explain the shift in your TC/resource positions during the project?" How did your view of the appropriate entry mode change over the time of the project?

2 Inertia and the accumulation of specialised assets

2.1 Did your decision make it necessary to make changes to assets (product, pricing structure or financial matters) or capabilities (procedures, policy or know-how, etc.)?

3 Inter-organisational networks: relational inertia

3.1 Did you during the project gather information from and/or about your potential business partners which led to a more cautious approach (e.g., lower commitment entry mode or stricter payment term or stricter contracts, etc.?)

3.2 Was your entry mode decision mainly dictated of problems of the business environment or opportunities associated with partnerships with local firms?

4 Psychological biases and commitment: cognitive inertia; and managerial intentionality and external changes

4.1 Were you personally in favour of not-entering the Kenyan market and 'overruled'? 
4.2 How and by 'who or what' were you overruled? e.g., prioritisation of other markets (low hanging fruits), CEO's personal interest in African/developing world matters, technical department's lack of resource to make necessary product changes, finance department's intervention on pricing issues, change of strategy/policy, etc.)

5 Expectations and result

5.1 To what extent were your expectations of export fulfilled?

5.2 What do you think explains whether your expectations were met or not? 